\title{
Griefers versus the Griefed - what motivates them to play Massively Multiplayer Online Role-Playing Games?
}

\author{
Leigh Achterbosch ${ }^{1}$, Charlynn Miller ${ }^{2}$, Christopher Turville $^{3}$, Peter Vamplew ${ }^{4}$
}

1 - 4: Address: Sch of Science, Information Technology and Engineering, Federation University, Ballarat, Victoria, Australia

1: e-mail: I.achterbosch@federation.edu.au

\begin{abstract}
'Griefing' is a term used to describe when a player within a multiplayer online environment intentionally disrupts another player's game experience for his or her own personal enjoyment or gain. Every day a certain percentage of users of Massively Multiplayer Online Role-Playing Games (MMORPG) are experiencing some form of griefing. There have been studies conducted in the past that attempted to ascertain the factors that motivate users to play MMORPGs. A limited number of studies specifically examined the motivations of users who perform griefing (who are also known as 'griefers'). However, those studies did not examine the motivations of users subjected to griefing. Therefore, the aim of this paper is to examine the factors that motivate the subjects of griefing to play MMORPGs, as well as the factors motivating the griefers.

The authors conducted an online survey with the intention to discover the motivations for playing MMORPGs among those whom identified themselves as (i) those that perform griefing, and (ii) those who have been subjected to griefing. A previously devised motivational model by Nick Yee that incorporated ten factors was used to determine the respondents' motivational trends. In general, players who identified themselves as griefers were more likely to be motivated by all three 'achievement' sub-factors (advancement, game mechanics and competition) at the detriment of all other factors. The subjects of griefing were highly motivated by 'advancement' and 'mechanics', but they ranked 'competition' significantly lower (compared to the griefers). In addition, 'immersion' factors were rated highly by the respondents who were subjected to griefing, with a significantly higher rating of the 'escapism' factor (compared with rankings by griefers). In comparison to the griefers, the respondents subjected to griefing with many years' experience in the genre of MMORPGs, also placed a greater emphasis on the 'socializing' and 'relationship' factors. Overall, the griefers in this survey considered 'achievement' to be a prime motivating factor, whereas the griefed players tended to be motivated by all ten factors to a similar degree.
\end{abstract}

Keywords: MMO, MMOG, MMORPG, griefing, griefer, online game, victim, virtual world

Article Information

Received: July 2013

Accepted: February 2014

Available: online April 2014

Copyright of the author(s) @2014 • Reproduction rights owned by The Computer Games Journal Ltd @2014

\section{1: Introduction}

The video game genre known as the Massively Multiplayer Online Role-Playing Game (MMORPG) consists of multiplayer role-playing games that are played online over the Internet in a persistent virtual world, with hundreds or even thousands of people concurrently connected to the same server. A persistent world is one that continues to operate (with other people enjoying what the world has to 
offer), even when you log off and are not participating in it yourself. Players can log back in at any time and continue with their avatar at the point where they previously logged off. MMORPGs generally have quests or objectives with distinguishable goals, such as fighting enemies to gain experience, and accessory items that help to develop the player's character (avatar). ${ }^{1}$

Every day in MMORPGs and online virtual worlds, at least some users are experiencing what is known as 'griefing'. This is when a player within a multiplayer online environment intentionally disrupts another player's game experience for his or her own personal enjoyment or gain. A 'griefer' is the term given to the player that willingly causes this disruption. It was reported by the developer of the virtual world Second Life (Linden Labs, 2003) that $6.5 \%$ of active users report abuse every month, with close to 2000 reports every day. This is in the context of Second Life's user base of around 800,000 users (that had repeated logins during 2010). The Massively Multiplayer Online Role-Playing Game (MMORPG) genre consisted of a total population of over 21 million players in 2011. MMORPG playrs were estimated to have spent over US\$12 billion in 2012 through subscriptions and in-game transactions. ${ }^{2-10}$

Studies performed by Nick Yee and associated researchers have focused on the factors that motivate people to play MMORPGs. More specifically, limited research has been conducted to explore the motivations of griefers themselves. Foo and Koivisto (2004) created a taxonomy of griefer types in an attempt to define the action of griefing, with some motivations discovered for each type of griefer. Foo (2008) went further by defining this taxonomy as a 'grief-play' motivational model. Schell (2008) described some mechanics of MMORPGs that griefers can find enjoyment in, while Chen et al (2009) discovered how anonymity enables the griefer to blend in to the MMORPG community. ${ }^{2,11-17}$

Previous studies into MMORPG players' motivations have focused on either the general populace of MMORPGs, or they focused only on the griefer. This paper uses the motivational model devised and refined by Yee, with the aim to identify not only the motivations for playing MMORPGs of the griefer, but also the motivations of the players that are subjected to griefing in varying amounts and also how their motivations differ in comparison to those of griefers. Throughout this paper, those that perform griefing will be referred to as 'griefers', and those subjected to griefing will be referred to as 'griefed'. This study focuses on the motivations for playing MMORPGs, rather than the motivations causing grief. $^{13}$

If developers of MMORPGs can begin to understand the motivations of the end-user in playing their games, perhaps they can design the mechanics of their virtual game worlds to better accommodate them. In developing Guild Wars 2 (ArenaNet, 2012), the developer ArenaNet wanted to change the way the game mechanics of MMORPGs worked, in an effort to apply anti-griefing measures. In this, ArenaNet eradicated common MMORPG game mechanisms that are part of popular MMORPGs such as World of Warcraft (Blizzard Entertainment, 2004). Some game mechanics can be fun and engaging, but they may enable griefing - for example, 'mob camping' and 'ganking': 18

- $\quad$ Mob Camping involves a player patiently waiting in one area (camping) for certain enemies (mobs) to appear so they can kill them for the rewards, or for their game quest. In Guild Wars 2, ArenaNet allowed all players involved in a fight to gain the rewards, not just the player that initiated the combat. In this way players are no longer fighting for enemies and resources. However this system can be exploited by attacking every enemy you see engaged with another player. As long as you meet the game mechanic conditions of about $5 \%$ damage applied, you can gain full reward, whilst letting other players do all the work. ${ }^{2}$

- $\quad$ Ganking involves players typically attacking weakened, defenceless or inexperienced players for an easy kill, to the other player's detriment. ArenaNet established two separate areas that 
never intersect, one for player versus player (PvP) combat and one for player versus environment (PvE) combat (human players fighting programmed enemies), to divide these two diverse groups. However, some people like both forms of combat, and it can be an intense and exciting experience being attacked by another player under challenging conditions. ${ }^{16,19}$

This paper examines the motivations for playing MMORPGs among varying demographics, and their association with griefing.

\section{2: Research Design}

\section{1: The Motivational Model}

Yee (2002) attempted to discover the motivational factors influencing why people play MMORPGs, using questions that were structured from Bartle's (1996) early work with a Multi-User Dungeon player type model, and from his own previous study (in 2001) of the MMORPG EverQuest (Sony Online Entertainment, 1999). He discovered five significant motivational factors from the data obtained: 'relationship', 'immersion', 'grief', 'achievement' and 'leadership'. In continuing this research, Yee further refined these five significant factors: 'relationship', 'immersion', 'manipulation', 'achievement' and 'escapism'. $3,11-12,19$

Yee later revised the main motivational factors previously discovered to just three: 'achievement', 'social' and 'immersion'. A motivational model was formulated from this data to discover the motivations of the player to play MMORPGs. This three-factor model was later used to discover the demographics and motivations of MMORPG players. The three factors broken down into ten more manageable sub-factors are as follows: ${ }^{13,14}$

\section{Achievement}

- $\quad$ Advancement - the desire to gain power, progress rapidly, and accumulate in-game symbols of wealth or status.

- $\quad$ Mechanics - having an interest in analyzing the underlying rules and system in order to optimize character performance.

- $\quad$ Competition - the desire to challenge and compete with others.

\section{Social}

- $\quad$ Socializing - having an interest in helping and chatting with other players.

- $\quad$ Relationship - the desire to form long-term meaningful relationships with others.

- $\quad$ Teamwork - deriving satisfaction from being part of a group effort.

\section{Immersion}

- $\quad$ Discovery - finding and knowing things that most other players don't know about.

- $\quad$ Role-Playing - creating a persona with a background story and interacting with other players to create an improvised story.

- $\quad$ Customization - having an interest in customizing the appearance of their character.

- $\quad$ Escapism - using the online environment to avoid thinking about real life problems. 


\section{2: Survey Design}

A survey was developed in order to gather the data needed for this research from a wide audience of MMORPG players. In order to gather a large overarching viewpoint from a global audience, the survey was chosen over more intensive methods such as interviews. The intent of the survey was to discover what motivates those that initiate griefing (the griefers) (compared to those that are subjected to griefing (the griefed)) to play MMORPGs, using the previously established motivational model developed by Yee. ${ }^{13}$

First, a pilot survey was produced and circulated among students of the computer game degree at the Ballarat campus of Federation University, Australia. The pilot survey led to some restructuring and rewording, and was used to ascertain that Yee's model was a good fit in determining the motivations of griefers and the griefed, with regards to why they play MMORPGs.

The final survey that went live globally gave a description of the term 'griefing' as identified in this paper. It also described the ten motivational factors so that respondents had a full understanding of the survey terminology. This is provided in Appendix A.

The survey questioned respondents on the full subset of ten motivational factors (with definitions provided), as well as gathering the respondents' demographics and their association to griefing. The motivational factors were scored by respondents from 'highly motivating' to 'zero motivation'. Association to griefing was broken down in to the amount of each - for example, performing, witnessing, and/or being subjected to the actions of griefing - in varying degrees from 'never' to 'always'. The full survey results are provided in the Appendix B.

\section{3: Survey Response}

Many invitations to the survey were circulated via popular MMORPG forums, in which the invitation remained open for two months. These attracted 1188 respondents, of which 1028 had answered all questions and had completed the survey. These respondents were self-selected and gave consent to use their answers upon entering the survey.

\section{4: Methodology}

For every motivational factor, a backwards elimination regression was conducted to identify the best model that included any significant independent variables and their interactions. All lower order terms were included if interaction was present. All of the demographic variables, the players' association to griefing, and all interactions were examined against each and every one of the motivational factors in these regression procedures.

After obtaining the best model for each motivational factor, the significant variables and interactions were further analyzed using an analysis of variance (ANOVA) to further explain the nature of the effects present. Significant interactions were further analyzed using single effect tests of each category of one variable against the categories of another variable. Bonferroni corrections were used to adjust the $p$-values of the additional tests performed. Variables that were significant without interaction present were further analyzed using Tukey's post-hoc tests. 


\section{3: Results and Discussion}

\section{1: Demographics}

Table 1 outlines the demographics of the respondents. The survey respondents' gender from this study was predominantly male $(85.6 \%, \mathrm{~N}=1028)$. This value is within a few percent of results found in other studies (e.g. Griffiths et al, 2003; Parsons, 2005; Yee and Bailenson, 2007; Williams et al, 2008). The respondents were global, with larger concentrations residing in the United States $(42.8 \%)$, the United Kingdom (9.6\%), Australia (6.5\%) and Canada (6.5\%), with a large number aged between 22 and $30(43.4 \%)$. The respondents were quite experienced with the MMORPG genre with the majority of them having played them for between 5 and 10 years. The number of hours played per week by the respondents was a little lower than some other studies (e.g. Williams et al, 2008), but this may be because of the amount of respondents that have been subjected to griefing, with the theory that this griefing impacts upon the hours they wish to play MMORPGs. ${ }^{14,21-23,25}$

Table 1: Demographics

\begin{tabular}{|c|c|c|}
\hline \multicolumn{3}{|c|}{ Gender } \\
\hline Gender & $\mathbf{n}$ & $\%$ \\
\hline Female & 148 & 14.4 \\
\hline Male & 880 & 85.6 \\
\hline \multicolumn{3}{|c|}{ Age } \\
\hline Age range & $\mathbf{n}$ & $\%$ \\
\hline 16 to 17 & 91 & 8.9 \\
\hline 18 to 21 & 246 & 23.9 \\
\hline 22 to 30 & 446 & 43.4 \\
\hline 31 and over & 245 & 23.8 \\
\hline \multicolumn{3}{|c|}{ MMORPG Experience } \\
\hline Value & $\mathbf{n}$ & $\%$ \\
\hline Less than 2 years & 91 & 8.9 \\
\hline 2 to 5 years & 233 & 22.7 \\
\hline 5 to 10 years & 508 & 49.4 \\
\hline More than 10 years & 196 & 19.1 \\
\hline \multicolumn{3}{|c|}{ Hours of Play per Week } \\
\hline Value & $\mathbf{n}$ & $\%$ \\
\hline 10 or less & 407 & 39.6 \\
\hline 11 to 20 & 267 & 26.0 \\
\hline 21 to 30 & 194 & 18.9 \\
\hline 31 and over & 160 & 15.6 \\
\hline
\end{tabular}

\section{2: Comparing Motivational Studies}

To establish that the data obtained is in line with other MMORPG studies, the mean value for each motivational factor was tested against gender (Table 2). The results indicate that males prefer Achievement over females (especially the desire to compete), whereas females prefer Social and Immersion factors, particularly role-playing and escaping real life. Similar patterns were reported in a study by Yee and William (2008) of a general MMORPG populace. ${ }^{14}$ 
Table 2: means and standard deviation of motivation factors by gender

\begin{tabular}{|c|c|c|c|c|c|}
\hline \multicolumn{2}{|c|}{ Motivation factor } & \multicolumn{2}{|r|}{ Male } & \multicolumn{2}{|r|}{ Female } \\
\hline & & Mean & Standard deviation & Mean & Standard deviation \\
\hline Achievement & $\begin{array}{l}\text { Advancement } \\
\text { Mechanics } \\
\text { Competition }\end{array}$ & $\begin{array}{l}3.84 \\
3.76 \\
3.42\end{array}$ & $\begin{array}{l}1.144 \\
1.159 \\
1.347\end{array}$ & $\begin{array}{l}3.51 \\
3.36 \\
2.83\end{array}$ & $\begin{array}{l}1.237 \\
1.207 \\
1.440\end{array}$ \\
\hline Social & $\begin{array}{l}\text { Socializing } \\
\text { Relationship } \\
\text { Teamwork }\end{array}$ & $\begin{array}{l}3.52 \\
2.65 \\
3.61 \\
\end{array}$ & $\begin{array}{l}1.180 \\
1.296 \\
1.184 \\
\end{array}$ & $\begin{array}{l}3.71 \\
2.84 \\
3.66 \\
\end{array}$ & $\begin{array}{l}1.168 \\
1.344 \\
1.175 \\
\end{array}$ \\
\hline Immersion & $\begin{array}{l}\text { Discovery } \\
\text { Role-playing } \\
\text { Customization } \\
\text { Escapism }\end{array}$ & $\begin{array}{l}3.79 \\
2.19 \\
3.52 \\
3.28\end{array}$ & $\begin{array}{l}1.221 \\
1.300 \\
1.296 \\
1.426\end{array}$ & $\begin{array}{l}4.04 \\
2.60 \\
3.86 \\
3.70\end{array}$ & $\begin{array}{l}1.166 \\
1.442 \\
1.265 \\
1.383\end{array}$ \\
\hline
\end{tabular}

\section{3: Separating the Griefers from the Griefed}

The survey respondents' association to griefing was broken down into (i) those who performed griefing (the griefers), and (ii) those who are subjected to griefing (the griefed). Respondents were regarded as griefers if they reported performing griefing on $\geq 50 \%$ of their logged-in time. Griefing becomes a regular activity for these players, as much as (or more than) the defined goals of the game. A similar definition was used to define the griefed, as shown in the final rows of Table 3. Under these definitions, it was observed that there was only a small percentage of a difference between males and females who performed or were subjected to griefing. It should be noted that some players that regularly performed griefing were also regularly subjected to griefing, and in Figure 1 this is represented by the intersection between the two groups. For lack of any pre-defined terminology, this paper shall refer to the third group as 'intersectors' $(n=25)$.

Table 3: Association to Griefing

\begin{tabular}{|c|c|c|c|c|c|}
\hline \multicolumn{2}{|c|}{$\begin{array}{c}\text { How often does it happen while you are logged in } \\
\text { to MMORPGs? }\end{array}$} & \multicolumn{2}{|c|}{ Performed griefing } & \multicolumn{2}{|c|}{ Subjected to griefing } \\
\hline & & $\mathrm{n}$ & $\%$ & $n$ & $\%$ \\
\hline (Irregularly) & $\begin{array}{l}\text { Never } \\
\text { Very rarely } \\
\text { On occasion }\end{array}$ & $\begin{array}{l}305 \\
402 \\
225\end{array}$ & $\begin{array}{l}29.7 \\
39.1 \\
21.9\end{array}$ & $\begin{array}{c}30 \\
283 \\
549\end{array}$ & $\begin{array}{c}2.9 \\
27.5 \\
53.4\end{array}$ \\
\hline (Regularly) & $\begin{array}{l}\text { About half of the time } \\
\text { Most of the time } \\
\text { All of the time }\end{array}$ & $\begin{array}{l}41 \\
25 \\
30\end{array}$ & $\begin{array}{l}4.0 \\
2.4 \\
2.9\end{array}$ & $\begin{array}{l}87 \\
56 \\
23\end{array}$ & $\begin{array}{l}8.5 \\
5.4 \\
2.2\end{array}$ \\
\hline & TOTAL & 96 & 9.3 & 166 & 16.1 \\
\hline Gender & Male | Female & $12 \mid 84$ & \begin{tabular}{l|l|l}
8.1 & 9.5
\end{tabular} & $20 \mid 146$ & \begin{tabular}{l|l}
13.5 & 16.6
\end{tabular} \\
\hline
\end{tabular}




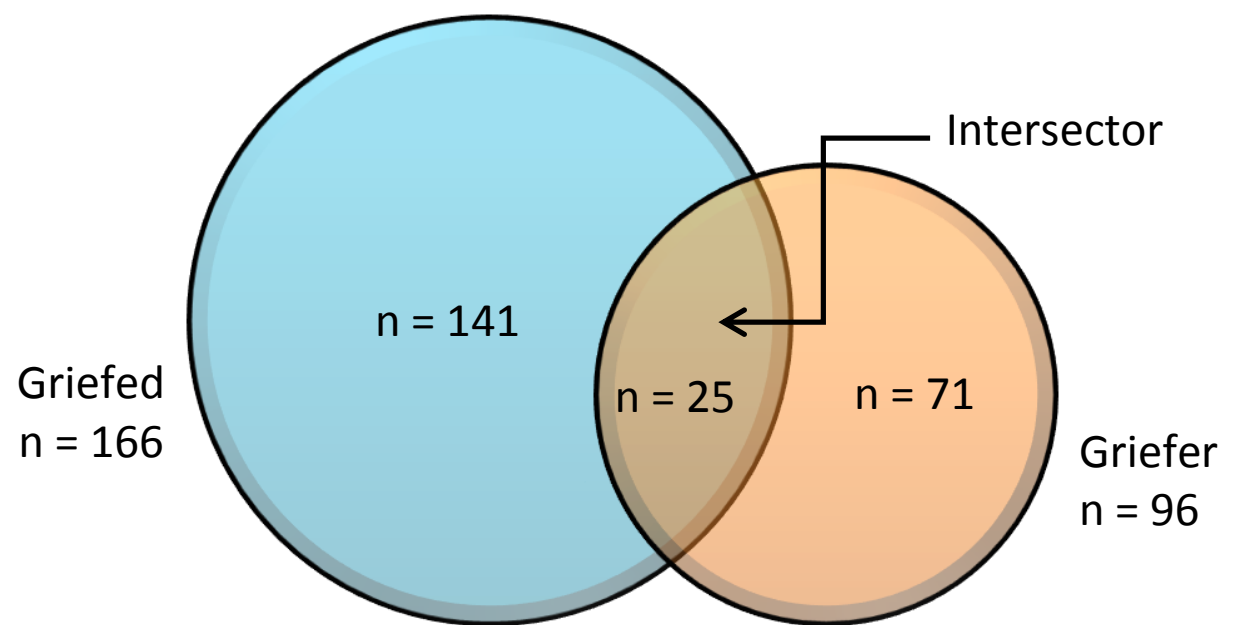

Figure 1: Association to Griefing

\section{4: Griefers versus the Griefed - motivation}

With the integrity of the data established, the primary intent of this paper may be explored. Rather than determining the motivational factors of the general MMORPG community (as has been achieved in some previous studies), this study identified the motivational factors in playing MMORPGs of the previously defined groups: griefers, griefed and intersectors. This comparison was firstly separated by gender, as outlined in Table 4. 'Competition' was the highest-rated motivational factor among players of both genders who performed griefing. On average, griefers also rated the other two 'achievement' category motivation factors ('mechanics' and 'competition') higher than everything else. By contrast, those subjected to griefing regularly rated one of the 'immersion' categories as the highest motivation in playing MMORPGs, with 'customization' (the interest of customizing your avatar) usually ranked the highest. The two 'achievement' factors - 'advancement' and 'mechanics' - while not ranked the highest by the griefed, were still rated quite highly on average. In light of this, it appeared that both griefers and the griefed in this survey enjoyed advancing their character's power and virtual wealth as well as understanding the mechanics of the game, and are motivated by these aspects to continue playing MMORPGs.

Table 4: Means of motivation factors by gender and association to griefing

\begin{tabular}{|c|c|c|c|c|c|c|c|}
\hline \multicolumn{2}{|c|}{ Motivation Factor } & \multicolumn{3}{|c|}{ Performed griefing } & \multicolumn{3}{|c|}{ Subjected to griefing } \\
\hline & & Female & Male & Both & Female & Male & Both \\
\hline & & $(n=12)$ & $(\mathrm{n}=84)$ & $(\mathrm{n}=96)$ & $(n=20)$ & $(n=146)$ & $(n=166)$ \\
\hline Achievement & $\begin{array}{l}\text { Advancement } \\
\text { Mechanics } \\
\text { Competition }\end{array}$ & $\begin{array}{l}3.67 \\
3.50 \\
4.42\end{array}$ & $\begin{array}{l}3.70 \\
3.71 \\
4.25\end{array}$ & $\begin{array}{l}3.70 \\
3.69 \\
\mathbf{4 . 2 7}\end{array}$ & $\begin{array}{l}3.45 \\
3.30 \\
3.05\end{array}$ & $\begin{array}{l}3.84 \\
3.86 \\
3.39\end{array}$ & $\begin{array}{l}3.79 \\
3.80 \\
3.35\end{array}$ \\
\hline Social & $\begin{array}{l}\text { Socializing } \\
\text { Relationship } \\
\text { Teamwork }\end{array}$ & $\begin{array}{l}3.50 \\
2.92 \\
3.58\end{array}$ & $\begin{array}{l}3.31 \\
2.44 \\
3.45\end{array}$ & $\begin{array}{l}3.33 \\
2.50 \\
3.47\end{array}$ & $\begin{array}{l}3.55 \\
2.90 \\
3.90\end{array}$ & $\begin{array}{l}3.60 \\
2.86 \\
3.58\end{array}$ & $\begin{array}{l}3.59 \\
2.86 \\
3.62\end{array}$ \\
\hline Immersion & $\begin{array}{l}\text { Discovery } \\
\text { Role-playing } \\
\text { Customization } \\
\text { Escapism }\end{array}$ & $\begin{array}{l}3.50 \\
2.92 \\
3.92 \\
3.42\end{array}$ & $\begin{array}{l}3.62 \\
2.05 \\
3.57 \\
2.96\end{array}$ & $\begin{array}{l}3.50 \\
2.16 \\
3.61 \\
3.02\end{array}$ & $\begin{array}{l}3.75 \\
2.60 \\
3.90 \\
4.00\end{array}$ & $\begin{array}{l}3.90 \\
2.29 \\
3.94 \\
3.45\end{array}$ & $\begin{array}{l}3.88 \\
2.33 \\
3.93 \\
3.52\end{array}$ \\
\hline
\end{tabular}

NB: 1 = not a motivating factor, 5 = a highly motivating factor. Values in bold indicate highest value for that demographic. 
The motivational factors in playing MMORPGs of different age groups were analyzed against griefers and the griefed (Table 5). 'Competition' was regularly rated high among all age groups of griefers; it was ranked the highest by griefers aged 11 and over, and slightly less so by players under 11 years old. Griefed players (aged under 11, or over 30) valued 'immersion' categories highly, but those aged between 11 and 20 valued 'achievement' factors highly.

Table 5: means of motivation factors by age (bold white text) and association to griefing

\begin{tabular}{|c|c|c|c|c|c|c|c|c|c|}
\hline \multicolumn{2}{|c|}{ Motivation Factor } & \multicolumn{4}{|c|}{ Performed griefing } & \multicolumn{4}{|c|}{ Subjected to griefing } \\
\hline & & $<11$ & $11-20$ & $21-30$ & $<30$ & $<11$ & $11-20$ & $21-30$ & $>30$ \\
\hline & & $(n=12)$ & $(n=30)$ & $(n=39)$ & $(n=15)$ & $(n=20)$ & $(n=49)$ & $(n=63)$ & $(n=34)$ \\
\hline \multirow[t]{3}{*}{ Achievement } & Advancement & 4.08 & 4.03 & 3.49 & 3.27 & 3.60 & 4.00 & 3.79 & 3.59 \\
\hline & Mechanics & 3.33 & 3.97 & 3.77 & 3.20 & 3.80 & 4.02 & 3.71 & 3.62 \\
\hline & Competition & 3.67 & 4.50 & 4.38 & 4.00 & 3.35 & 3.80 & 3.22 & 2.94 \\
\hline \multirow[t]{3}{*}{ Social } & Socializing & 3.67 & 3.47 & 3.36 & 2.73 & 4.00 & 3.73 & 3.40 & 3.50 \\
\hline & Relationship & 2.58 & 2.63 & 2.56 & 2.00 & 3.20 & 2.98 & 2.73 & 2.74 \\
\hline & Teamwork & 3.00 & 3.63 & 3.69 & 2.93 & 3.65 & 3.43 & 3.71 & 3.71 \\
\hline \multirow[t]{4}{*}{ Immersion } & Discovery & 3.75 & 3.70 & 3.67 & 3.13 & 4.15 & 3.71 & 3.78 & 4.15 \\
\hline & Role-playing & 2.00 & 2.33 & 2.18 & 1.87 & 2.65 & 2.08 & 2.24 & 2.65 \\
\hline & Customization & 3.42 & 3.80 & 3.41 & 3.93 & 3.75 & 3.94 & 3.79 & 4.29 \\
\hline & Escapism & 2.83 & 2.83 & 3.00 & 3.60 & 3.50 & 3.57 & 3.54 & 3.41 \\
\hline
\end{tabular}

NB: 1 = not a motivating factor, 5 = a highly motivating factor. Values in bold indicate highest value for that demographic.

Table 6 compares the motivational factors in playing MMORPGs among players that log in and play for different lengths of time per week in MMORPGs, versus their association to griefing. 'Competition' was the highest-rated motivational factor among all griefers who spent different amounts of time each week playing MMORPGs. The griefed players tended to value 'discovery' and 'customization' as the most motivational factors, irrespective of the number of hours spent playing MMORPGs.

Table 6: means of motivation factors by hours per week (bold white text) currently playing MMORPGs and association to griefing

\begin{tabular}{|c|c|c|c|c|c|c|c|c|c|}
\hline \multicolumn{2}{|c|}{ Motivation Factor } & \multicolumn{4}{|c|}{ Performed griefing } & \multicolumn{4}{|c|}{ Subjected to griefing } \\
\hline & & $<11$ & $11-20$ & $21-30$ & $<30$ & $<11$ & $11-20$ & $21-30$ & $>30$ \\
\hline & & $(n=34)$ & $(n=21)$ & $(n=21)$ & $(\mathrm{n}=20)$ & $(\mathrm{n}=60)$ & $(n=40)$ & $(n=41)$ & $(n=25)$ \\
\hline \multirow[t]{3}{*}{ Achievement } & Advancement & 3.65 & 3.43 & 3.71 & 4.05 & 3.67 & 3.83 & 3.98 & 3.73 \\
\hline & Mechanics & 3.24 & 3.86 & 4.29 & 3.65 & 3.70 & 3.72 & 4.07 & 3.68 \\
\hline & Competition & 3.97 & 4.48 & 4.52 & 4.30 & 3.37 & 3.37 & 3.22 & 3.48 \\
\hline \multirow[t]{3}{*}{ Social } & Socializing & 2.85 & 3.76 & 3.67 & 3.85 & 3.48 & 3.57 & 3.93 & 3.32 \\
\hline & Relationship & 2.15 & 2.86 & 2.62 & 2.60 & 2.92 & 2.63 & 3.24 & 2.48 \\
\hline & Teamwork & 3.26 & 3.81 & 3.43 & 3.50 & 3.58 & 3.47 & 3.90 & 3.48 \\
\hline \multirow[t]{4}{*}{ Immersion } & Discovery & 3.53 & 3.71 & 3.52 & 3.70 & 3.90 & 3.87 & 4.27 & 3.20 \\
\hline & Role-playing & 2.21 & 2.38 & 1.86 & 2.15 & 2.35 & 2.23 & 2.49 & 2.16 \\
\hline & Customization & 3.35 & 3.71 & 3.81 & 3.75 & 3.80 & 3.90 & 4.10 & 4.04 \\
\hline & Escapism & 2.82 & 3.24 & 3.05 & 3.10 & 3.37 & 3.43 & 3.56 & 3.96 \\
\hline
\end{tabular}

NB: 1 = not a motivating factor, 5 = a highly motivating factor. Values in bold indicate highest value for that demographic. 
Table 7 compares the motivational factors in playing MMORPGs, between griefers and the griefed with varying experience within the MMORPG genre (in amount of years having played MMORPGs). Once more it was observed that griefers valued 'achievement' highly, whereas griefed players tended to value 'immersion' highly.

Table 7: means of motivation factors by MMORPG experience in years (bold white text) and association to griefing

\begin{tabular}{|c|c|c|c|c|c|c|c|c|c|}
\hline \multicolumn{2}{|c|}{ Motivation Factor } & \multicolumn{4}{|c|}{ Performed griefing } & \multicolumn{4}{|c|}{ Subjected to griefing } \\
\hline & & $<2$ & $2-5$ & $5-10$ & $>10$ & $<2$ & $2-5$ & $5-10$ & $>10$ \\
\hline & & $(n=6)$ & $(n=19)$ & $(n=42)$ & $(n=29)$ & $(n=18)$ & $(n=41)$ & $(n=75)$ & $(n=32)$ \\
\hline Achievement & $\begin{array}{l}\text { Advancement } \\
\text { Mechanics } \\
\text { Competition }\end{array}$ & $\begin{array}{l}4.33 \\
2.83 \\
3.83\end{array}$ & $\begin{array}{l}3.42 \\
3.89 \\
3.74\end{array}$ & $\begin{array}{l}3.81 \\
3.69 \\
4.52\end{array}$ & $\begin{array}{l}3.59 \\
3.72 \\
4.34\end{array}$ & $\begin{array}{l}3.67 \\
3.50 \\
3.22\end{array}$ & $\begin{array}{l}4.05 \\
3.83 \\
3.37\end{array}$ & $\begin{array}{l}3.83 \\
3.87 \\
3.45\end{array}$ & $\begin{array}{l}3.44 \\
3.75 \\
3.16\end{array}$ \\
\hline Social & $\begin{array}{l}\text { Socializing } \\
\text { Relationship } \\
\text { Teamwork }\end{array}$ & $\begin{array}{l}2.50 \\
2.17 \\
2.67\end{array}$ & $\begin{array}{l}3.37 \\
2.47 \\
3.68\end{array}$ & $\begin{array}{l}3.67 \\
2.76 \\
3.52\end{array}$ & $\begin{array}{l}3.00 \\
2.21 \\
3.41\end{array}$ & $\begin{array}{l}3.17 \\
2.39 \\
3.22\end{array}$ & $\begin{array}{l}3.56 \\
2.88 \\
3.63\end{array}$ & $\begin{array}{l}3.64 \\
2.87 \\
3.63\end{array}$ & $\begin{array}{l}3.75 \\
3.09 \\
3.81\end{array}$ \\
\hline Immersion & $\begin{array}{l}\text { Discovery } \\
\text { Role-playing } \\
\text { Customization } \\
\text { Escapism }\end{array}$ & $\begin{array}{l}4.00 \\
2.83 \\
3.67 \\
2.33 \\
\end{array}$ & $\begin{array}{l}3.37 \\
1.89 \\
3.53 \\
3.16 \\
\end{array}$ & $\begin{array}{l}3.60 \\
2.19 \\
3.52 \\
2.79 \\
\end{array}$ & $\begin{array}{l}3.69 \\
2.14 \\
3.79 \\
3.41\end{array}$ & $\begin{array}{l}3.72 \\
2.83 \\
3.56 \\
2.94 \\
\end{array}$ & $\begin{array}{l}4.00 \\
2.54 \\
4.12 \\
3.73 \\
\end{array}$ & $\begin{array}{l}3.77 \\
2.08 \\
3.83 \\
3.59 \\
\end{array}$ & $\begin{array}{l}4.06 \\
2.34 \\
4.16 \\
3.41 \\
\end{array}$ \\
\hline
\end{tabular}

NB: 1 = not a motivating factor, 5 = a highly motivating factor. Values in bold indicate highest value for that demographic.

The ten motivational factors were analyzed individually to discover statistically significant differences between the respondents' demographics and their association to griefing using the methods described previously in this paper. The analysis confirmed that the number of hours per week that a respondent spent on playing an MMORPG (Table 6) had no significance to the value they placed on each motivational factor. This was also true for gender (Table 4), but it must be noted that there were only 12 regular female griefers from a pool of 148 female respondents $(8.1 \%, n=148)$, and there were 20 female griefed players $(13.5 \%, n=148)$. The low number of females may have contributed to the insignificant differences between gender, as the $p$ value for the motivational factor 'escapism' was almost showing a statistical significant difference $(p=0.081)$, as was 'role-playing' $(p=0.085)$ between male and females. Further research with more female griefers will be needed to confirm whether or not there are significant differences between the genders, in terms of how they value escapism and role-playing.

In an effort to further analyse the players' rankings of 'competition', an analysis of variance and the interaction was conducted to explore the effect of age, association to griefing and their interaction. The interaction was significant between age and association to griefing $(p=0.003)$, suggesting there are differences in how highly players rank 'competition' scores, and such differences exist between griefers and the griefed, and among different age groups. The single effect post-hoc analysis showed that among 16 to 17 year old players, the griefers' ranking of 'competition' was significantly higher than that by intersectors ( $\bar{x}=3.67, s=1.723$; and, $\bar{x}=1.67, s=1.155$, respectively) $(p=0.040)$. Among 18 to 21 year olds, the 'competition' scores were higher for griefers ( $\bar{x}=4.50, \mathrm{~s}=0.861)$, compared to rankings by the griefed $(\bar{x}=3.80, s=1.154)(p=0.032)$. Among 22 to 30 year olds, the griefed $(\bar{x}=3.22$, $s=1.507)$ had lower 'competition' scores compared to scores by griefers $(\bar{x}=4.38, s=1.091)$ and by intersectors $(\bar{x}=4.89, s=0.333)(p=0.000)$.

As shown in Appendix B, there was an indication that the more often the respondent performed griefing, the higher his or her ranking of 'competition'. Conducting an analysis of variance between respondents confirmed this pattern $(p=0.000)$. Overall, this indicates that competition as a 
motivational factor is valued considerably higher by griefers (and intersectors) than by the griefed (especially those griefers who performed griefing more regularly) in the 18 to 30 year old age groups. However, there were no significant differences in the rankings of 'competition' by griefers and other groups among the older respondents.

A significant interaction between experience (the amount of time in years respondents had spent playing MMORPGs) and association to griefing was found for 'socializing' ( $p=0.026)$ and 'relationship' $(p=0.039)$, indicating that there are differences between the griefed and other groups that depends on their amount of genre experience. The griefed $(\bar{x}=3.75, s=1.218)$ had significantly higher 'socializing' scores than intersectors $(\bar{x}=2.43, s=0.976)$ but only if they possessed more than 10 years MMORPG experience $(p=0.024)$. No significant differences were found for those with less experience. Similarly, the griefed ( $\bar{x}=3.09, \mathrm{~s}=1.353)$ had significantly higher 'relationship' scores than intersectors $(\bar{x}=1.71$, $s=0.756)$ but again, only if they possessed more than 10 years MMORPG experience $(p=0.028)$. Almost of significance $(p=0.052)$ was the pattern suggesting that the griefed $(\bar{x}=3.09, s=1.353)$ had higher 'relationship' scores than griefers $(\bar{x}=2.21, \mathrm{~s}=1.346)$. While no differences were found for those with less experience, conceivably more research and a larger sample size may determine whether this difference is real.

Within the 'immersion' category it was observed (Appendix B) that the more often respondents expressed that they were subjected to griefing, the higher their rating of 'customization'. This was also confirmed in an analysis of variance test $(p=0.002)$. There are two possible hypotheses for this outcome:

1. The more that players enjoy customizing their in-game characters, the more attached they become, and therefore it is conceivable that they are more susceptible to griefing or more likely to regard other players' actions as griefing. ${ }^{24}$

2. The way the player customizes an avatar may be a reason for the griefer to select it as a target of griefing.

Finally, in terms of the 'escapism' motivational factor, a statistically significant difference between griefers and the griefed $(p=0.006)$ was found. The single effect post-hoc analysis indicated that the mean score for the griefed $(\bar{x}=3.52, \mathrm{~s}=1.404)$ was significantly higher than that for the griefers $(\overline{\boldsymbol{x}}$ $=3.02, s=1.569)(p=.019)$. It is possible that the griefed respondents' desire for escapism from their real life concerns renders them more vulnerable to griefing and attacks within the game.

\section{4: Conclusion}

As expected, the respondents who identified themselves as players who performed griefing, were more likely to rate the motivational factor 'competition' higher than those who were subjected to griefing, due to the competitive nature of the former. The more often the respondent performed griefing, the higher his/her rating of 'competition' as a motivational factor. Similarly, the more often a player was subjected to griefing, the higher his/her ranking of 'customization'. The griefed players' mean rating of 'immersion' was higher than that by griefers, especially 'escapism', which was found to be significantly higher.

A less expected outcome was similar ranking of 'advancement' and 'mechanics' by griefers and griefed players. Therefore, it is possible that it is not just the griefers who wish to have powerful characters and who want to know the intricacies of the game mechanics. It may be the case that in order to 'stand a fighting chance' against the griefing disruptions to their game, griefed players aim to 
accumulate power and understand how to use that power just as much as the griefers do. The difference is that the griefers in this study valued the 'achievement' factors higher than 'social' and 'immersion' categories, showing that their focus is to advance, learn the game mechanics and compete at the detriment of all other actions, in contrast to players who are subjected to griefing. It was discovered that griefed players in this study valued 'socializing' and 'relationship' more highly than the other categories. However, this was only significant for respondents who had played MMORPGs for more than 10 years.

Overall, the griefers in this study valued the 'achievement' factors more highly than other factors, whereas the griefed players made a more balanced valuation of the ten factors. The patterns discussed in this paper shall be explored in future research via interviews with griefers and griefed MMORPG players. It is hoped that the results will help MMORPG developers better understand their players, and design more stimulating game mechanics for all involved.

\section{Acknowledgements}

Leigh Achterbosch acknowledges the assistance of Grant Meredith in creating a survey suitable for a world-wide audience, and thanks Savin Chand for assisting with statistical calculations.

\section{References}

1. Achterbosch, L., Pierce, R. \& Simmons, G. (2008) 'Massively Multiplayer Online Role-Playing Games: the Past, Present, and Future' Computing Entertainment 5(4), pp.9:1 - 9:33.

2. Foo, C.Y. \& Koivisto, E.M.I. (2004) 'Defining Grief Play in MMORPGs: Player and Developer Perceptions' Proceedings of the 2004 ACM SIGCHI International Conference on Advances in Computer Entertainment Technology, New York, NY, USA, pp. 245-250.

3. Bartle, R.A. (2007) 'What to call a Griefer?' Terranova. Available from: http://terranova.blogs.com/terra_nova/2007/10/what-to-call-a-.html [accessed 10 May 2012]

4. Adrian, A. (2010) 'Beyond Griefing: Virtual Crime' Computer Law \& Security Review 26(6) pp.640-648.

5. Lin, H. \& Sun, C. (2005) 'The "White-eyed" Player Culture: Grief Play and Construction of Deviance in MMORPGs" Changing Views: Worlds in Play: Proceedings of the 2005 Digital Games Research Association Conference, Vancouver, British Columbia, Canada.

6. Chesney, T., Coyne, I., Logan, B. \& Madden, N. (2009) 'Griefing in Virtual Worlds: Causes, Casualties and Coping Strategies' Information Systems Journal 19(6) pp.525-548.

7. $\quad$ Linden, N. (2011) The Second Life Economy in Q4 2010. Available from: http://community.secondlife.com/t5/Featured-News/The-Second-Life-Economy-in-Q4-2010/ba-p/674618 [accessed 20 March 2012]

8. MMO Data (2011) MMOData Charts. Available from: http://www.mmodata.net/ [accessed 29 July 2011].

9. Hartman, M. (2011) MMO Subscriber Populations. Available from: http://www.brighthub.com/videogames/mmo/articles/35992.aspx [accessed 7 February 2011].

10. SuperData \& Newzoo. (2012) Global MMO Games Spending Exceeds \$12bn. Available from: http://www.newzoo.com/press-releases/global-mmo-games-spending-exceeds-12bn/ [accessed 14 October 2012] 
11. Yee, N. (2002) Facets: 5 Motivational Factors for Why People Play MMORPGs. Available from: http://www.nickyee.com/facets/home.html [14 April 2011]

12. Yee, N. (2006a) 'The Demographics, Motivations, and Derived Experiences of Users of Massively MultiUser Online Graphical Environments' Presence: Teleoperators and Virtual Environments 15(3) pp.309329.

13. Yee, N. (2006b) 'Motivations for Play in Online Games' CyberPsychology \& Behavior 9(6) pp.772-775.

14. Williams, D., Yee, N. \& Caplan, S.E. (2008) 'Who Plays, How Much, and Why? Debunking the Stereotypical Gamer Profile' Journal of Computer-Mediated Communication 13(4) pp.993-1018.

15. Foo, C.Y. (2008) Grief Play Management. VDM Verlag, Germany.

16. Schell, J. (2008) The Art of Game Design: A Book of Lenses. $1^{\text {st }}$ Ed, Morgan Kaufmann Publishers, Massachussets, United States.

17. Chen, V.H., Duh, H.B. \& Ng, C.W. (2009) 'Players Who Play to Make Others Cry: the Influence of Anonymity and Immersion' Proceedings of the International Conference on Advances in Computer Entertainment Technology, New York, NY, USA, pp.341-344.

18. Procopio, R. (2011) Massive: Guild Wars 2 - Reinventing a Genre. Available from: http://www.unwinnable.com/2011/03/24/massive-guild-wars-2-reinventing-a-genre/ [accessed 26 March 2011]

19. Yee, N. (2001) The Norrathian Scrolls: a Study of Everquest (version 2.5). Available from: http://wwww.nickyee.com/eqt/demographics.html [accessed 20 January 2013]

20. Goguen, S. 2009, 'Dual Wielding Morality: World of Warcraft and the Ethics of Ganking' Proceedings of The Philosophy of Computer Games Conference 2009, Oslo, Norway.

21. Bartle, R.A. (1996) 'Players Who Suit MUDs' Journal of MUD Research 1(1)

22. Griffiths, M., Davies, M. \& Chappell, D. (2003) 'Breaking the Stereotype: the Case of Online Gaming' Cyberpsychological Behavior 6(1) p81.

23. Parsons, J.M. (2005) An examination of Massively Multiplayer Online Role-Playing Games as a Facilitator of Internet Addiction. PhD thesis, University of lowa, University of lowa.

24. Ducheneaut, N., Wen, M., Yee, N. and Wadley, G. (2009) 'Body and Mind: A Study of Avatar Personalization in Three Virtual Worlds.' Proceedings of the SIGCHI Conference on Human Factors in Computing Systems, Boston, MA, USA, pp.1151-1160.

25. Yee, N. \& Bailenson, J.N. (2007) 'The Proteus Effect: The Effect of Transformed Self-Representation on Behavior' Human Communication Research 33 pp.271-290.

\section{Ludography}

ArenaNet (2012). Guild Wars 2. NCsoft.

Blizzard Entertainment (2004). World of Warcraft. Blizzard Entertainment.

Linden Labs (2003). Second Life. Linden Labs.

Sony Online Entertainment (1999). EverQuest. Sony Online Entertainment. 


\section{APPENDIX A}

\section{Survey Questions}

1. Gender:
a. Female
b. Male

2. Age:
a. 16 to 17
b. 18 to 21
c. 22 to 30
d. 31 and over

3. Country of Residence:

a. Drop down list containing 249 Countries to choose from.

4. How many hours per week do you currently play MMORPG(s)?
a. Less than 10
b. 11 to 20
c. 21 to 30
d. More than 30

5. How long have you been playing MMORPG(s)?
a. Less than 2 years
b. 2 to 5 years
c. 5 to 10 years
d. More than 10 years

6. What motivates you to play MMORPG(s)? Please score the following ten factors of what motivates you to play MMORPG(s) from 1 to 5 .

$1=$ this factor does not motivate me at all. to $5=$ this is a very high motivating factor.

a. Advancement-The desire to gain power, progress rapidly, and accumulate in-game symbols of wealth or status.

b. Mechanics - Having an interest in analyzing the underlying rules and system in order to optimize character performance.

c. Competition - The desire to challenge and compete with others.

d. Socializing - Having an interest in helping and chatting with other players.

e. Relationship - The desire to form long-term meaningful relationships with others.

f. Teamwork-Deriving satisfaction from being part of a group effort.

g. Discovery - Finding and knowing things that most other players don't know about.

h. Role-Playing - Creating a persona with a background story and interacting with other players to create an improvised story.

i. Customization - Having an interest in customizing the appearance of their character.

j. Escapism - Using the online environment to avoid thinking about real life problems.

7. Please identify how often the following statements apply to you while logged in to an MMORPG: Never | Very rarely| On occasion | About half of the time | Most of the time|All of the time
a. I have been subjected to griefing
b. I have performed griefing
c. I have witnessed griefing 


\section{APPENDIX B}

\begin{tabular}{|c|c|c|c|c|c|c|c|}
\hline \multicolumn{8}{|c|}{ Motivation Factors by Association to Griefing } \\
\hline & \multirow[b]{2}{*}{$\begin{array}{l}\text { Motivation } \\
\text { Factor }\end{array}$} & \multicolumn{3}{|l|}{ Performed Griefing } & \multicolumn{3}{|l|}{ Subjected to Griefing } \\
\hline & & Amount & Mean & $\begin{array}{l}\text { Std. } \\
\text { Dev }\end{array}$ & Amount & Mean & $\begin{array}{l}\text { Std. } \\
\text { Dev }\end{array}$ \\
\hline \multirow[t]{15}{*}{ Achievement } & \multirow[t]{5}{*}{ Advancement } & Very rarely & 3.87 & 1.069 & Very rarely & 3.81 & 1.187 \\
\hline & & On occasion & 3.91 & 1.134 & On occasion & 3.78 & 1.139 \\
\hline & & About half of the time & 3.76 & 1.280 & About half of the time & 3.85 & 1.040 \\
\hline & & Most of the time & 4.04 & 1.428 & Most of the time & 3.84 & 1.218 \\
\hline & & All of the time & 3.33 & 1.668 & All of the time & 3.43 & 1.590 \\
\hline & \multirow[t]{5}{*}{ Mechanics } & Very rarely & 3.72 & 1.128 & Very rarely & 3.67 & 1.221 \\
\hline & & On occasion & 3.77 & 1.141 & On occasion & 3.70 & 1.121 \\
\hline & & About half of the time & 3.76 & 1.019 & About half of the time & 3.70 & 1.142 \\
\hline & & Most of the time & 3.68 & 1.492 & Most of the time & 4.02 & 1.213 \\
\hline & & All of the time & 3.60 & 1.380 & All of the time & 3.61 & 1.559 \\
\hline & \multirow[t]{5}{*}{ Competition } & Very rarely & 3.30 & 1.323 & Very rarely & 3.38 & 1.384 \\
\hline & & On occasion & 3.88 & 1.211 & On occasion & 3.31 & 1.359 \\
\hline & & About half of the time & 4.15 & 1.108 & About half of the time & 3.23 & 1.370 \\
\hline & & Most of the time & 4.60 & .913 & Most of the time & 3.50 & 1.465 \\
\hline & & All of the time & 4.17 & 1.315 & All of the time & 3.43 & 1.472 \\
\hline \multirow[t]{15}{*}{ Social } & \multirow{5}{*}{ Socializing } & Very rarely & 3.62 & 1.144 & Very rarely & 3.46 & 1.232 \\
\hline & & On occasion & 3.59 & 1.154 & On occasion & 3.60 & 1.130 \\
\hline & & About half of the time & 3.61 & 1.070 & About half of the time & 3.60 & 1.146 \\
\hline & & Most of the time & 2.96 & 1.241 & Most of the time & 3.70 & 1.127 \\
\hline & & All of the time & 3.27 & 1.596 & All of the time & 3.30 & 1.579 \\
\hline & \multirow[t]{5}{*}{ Relationship } & Very rarely & 2.83 & 1.271 & Very rarely & 2.49 & 1.278 \\
\hline & & On occasion & 2.70 & 1.298 & On occasion & 2.76 & 1.293 \\
\hline & & About half of the time & 2.61 & 1.222 & About half of the time & 2.79 & 1.365 \\
\hline & & Most of the time & 2.52 & 1.447 & Most of the time & 3.00 & 1.265 \\
\hline & & All of the time & 2.33 & 1.422 & All of the time & 2.78 & 1.506 \\
\hline & \multirow[t]{5}{*}{ Teamwork } & Very rarely & 3.64 & 1.123 & Very rarely & 3.52 & 1.247 \\
\hline & & On occasion & 3.63 & 1.207 & On occasion & 3.67 & 1.151 \\
\hline & & About half of the time & 3.73 & 1.162 & About half of the time & 3.82 & 1.051 \\
\hline & & Most of the time & 3.12 & 1.236 & Most of the time & 3.55 & 1.190 \\
\hline & & All of the time & 3.40 & 1.499 & All of the time & 3.04 & 1.492 \\
\hline \multirow[t]{20}{*}{ Immersion } & \multirow[t]{5}{*}{ Discovery } & Very rarely & 3.84 & 1.176 & Very rarely & 3.73 & 1.269 \\
\hline & & On occasion & 3.76 & 1.277 & On occasion & 3.88 & 1.162 \\
\hline & & About half of the time & 4.00 & 1.323 & About half of the time & 3.93 & 1.169 \\
\hline & & Most of the time & 3.36 & 1.497 & Most of the time & 3.93 & 1.234 \\
\hline & & All of the time & 3.27 & 1.437 & All of the time & 3.57 & 1.472 \\
\hline & \multirow[t]{5}{*}{ Role-Playing } & Very rarely & 2.24 & 1.293 & Very rarely & 2.20 & 1.347 \\
\hline & & On occasion & 2.13 & 1.322 & On occasion & 2.25 & 1.288 \\
\hline & & About half of the time & 2.41 & 1.643 & About half of the time & 2.47 & 1.421 \\
\hline & & Most of the time & 2.12 & 1.481 & Most of the time & 2.21 & 1.436 \\
\hline & & All of the time & 1.83 & 1.289 & All of the time & 2.04 & 1.397 \\
\hline & \multirow[t]{5}{*}{ Customization } & Very rarely & 3.61 & 1.247 & Very rarely & 3.36 & 1.373 \\
\hline & & On occasion & 3.47 & 1.313 & On occasion & 3.58 & 1.287 \\
\hline & & About half of the time & 4.00 & 1.466 & About half of the time & 3.89 & 1.224 \\
\hline & & Most of the time & 3.36 & 1.319 & Most of the time & 3.96 & .914 \\
\hline & & All of the time & 3.30 & 1.343 & All of the time & 4.04 & 1.261 \\
\hline & \multirow[t]{5}{*}{ Escapism } & Very rarely & 3.45 & 1.392 & Very rarely & 3.05 & 1.480 \\
\hline & & On occasion & 3.31 & 1.436 & On occasion & 3.47 & 1.375 \\
\hline & & About half of the time & 3.00 & 1.565 & About half of the time & 3.59 & 1.317 \\
\hline & & Most of the time & 2.76 & 1.480 & Most of the time & 3.30 & 1.476 \\
\hline & & All of the time & 3.27 & 1.660 & All of the time & 3.78 & 1.536 \\
\hline
\end{tabular}

